\title{
Neurosyphilis Presenting with Ptosis and Diplopia as the First Complaints: Case Report
}

\author{
İlk Yakınma Olarak Pitoz ve Diplopi ile Başvuran Nörosifiliz: Olgu Sunumu
}

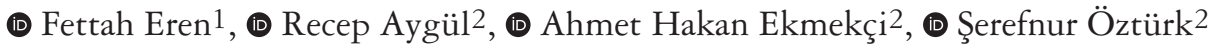 \\ 1 University of Health Sciences, Konya Training and Research Hospital, Clinic of Neurology, Konya, Turkey \\ 2Selcuk University Faculty of Medicine, Department of Neurology, Konya, Turkey
}

\begin{abstract}
Syphilis is a spirochete disease that occurs due to Treponema pallidum infection. It can be sexually transmitted and can be transmitted from mother to baby vertically. Neurological involvement is more common in the late period. The use of common antibiotics may alter the natural course of the disease. Because of this, syphilis may present with different neurological findings. A 49-year-old male patient was admitted to our clinic with complaints of fluctuating double vision and droopy left eyelid for two months. In the neurological examination, pupils were mid-dilated, direct and indirect pupillary light reflexes were bilaterally absent, movements of the left eye in all directions and rightward movement of the right eye were restricted. Also, bilateral ptosis was detected. Brain magnetic resonance imaging and electrophysiological studies including repetitive stimulation were normal. Syphilis was diagnosed with blood and cerebrospinal fluid (CSF) tests. He was treated with long-term high-dose intravenous penicillin. Ocular findings are an important indicator of neurosyphilis. Ocular involvement due to primary disease process is rare. If meningitis-related CSF absorption defect develops, eye movement disorders and pupil abnormalities may occur. The diagnosis of neurosyphilis may be delayed due to different clinical manifestations. Neurosyphilis should be considered in case of ocular findings.
\end{abstract}

Keywords: Syphilis, neurosyphilis, ophthalmoparesis, diplopia, ptosis

Öz

Sifiliz, Treponema pallidum'a bağlı olarak gelişen bir spiroket hastalığıdır. Cinsel yolla bulaşabilir ve anneden bebeğe diklemesine geçebilir. Nörolojik tutulum daha çok geç dönemde görülür. Yaygın antibiyotik kullanımı hastalığın doğal seyrini de ğiştirebilir. Bu nedenle sifiliz farklı nörolojik bulgular ile ortaya çıkabilir. Kırk dokuz yaşında erkek hasta iki aydır dalgalanma gösteren çift görme ve sol göz kapağında düşüklük şikayeti ile başvurdu. Nörolojik muayenesinde; pupiller mid-dilate idi. Bilateral direkt ve indirekt pupil sşık cevabı alınamıyordu. Sol gözde tüm yönlere ve sağ gözde sadece sağa bakışta hareket kısıtlılığı vardı. Aynı zamanda bilateral pitozu olduğu görüldü. Beyin manyetik rezonans görüntüleme ve repetetif uyarım dahil elektrofizyolojik incelemeler normaldi. Kan ve beyin omurilik sıvısı (BOS) incelemeleri sonucunda sifiliz tanısı konuldu. Uzun süre yüksek doz intravenöz penisilin tedavisi uygulandı. Oküler bulgular geç dönem nörosifilizin önemli bir göstergesidir. Hastalığın primer etkisi ile meydana gelen oküler tutulum oldukça nadirdir. Eğer menenjite bağlı BOS absorbsiyon bozukluğu gelişirse, göz hareket bozukluğu ve pupil anormallikleri görülebilir. Nörosifilizin tanısı farklı klinik görünümleri nedeni ile gecikebilmektedir. Oküler bulgular varlığında nörosifiliz tanısı da akla gelmelidir.

Anahtar Kelimeler: Sifiliz, nörosifiliz, oftalmoparezi, diplopi, pitoz

\section{Introduction}

Syphilis is a spirochete disease caused by Treponema pallidum. It is transmitted by sexual contact or vertically from mother to child. It is more common in the Western World and Africa, especially in the last 10 years. Neurosyphilis, the involvement of central nervous system by syphilis infection, can affect $40 \%$ of the untreated patients (1). There are 4 types of central nervous system involvement caused by syphilis: Syphilitic meningitis, meningovascular syphilis, parenchymal syphilis and gummatous syphilis. Acute syphilitic meningitis, basilar type presents with multiple cranial nerve involvement. Vestibulocochlear (42\%) and facial $(41 \%)$ nerves are the most commonly affected ones followed by the other cranial nerves $(2,3)$.

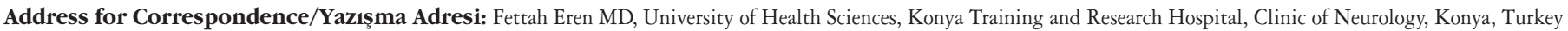
Phone: +905058604146 E-mail: dreren42@hotmail.com ORCID ID: orcid.org/0000-0001-6834-0827

Received/Gelis Tarihi: 14.10.2017 Accepted/Kabul Tarihi: 27.12.2017

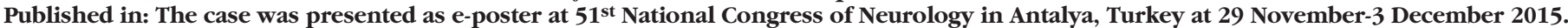


There had been a significant decrease in the number of syphilis cases all over the world after the initiation of penicillin therapy. Following an increase in the frequency of AIDS, syphilis has also started to be seen more frequently. Due to common use of antibiotics and increased frequency of HIV infection; neurosyphilis may present with various clinical features. The frequency of atypical forms of neurosyphilis increased to $86 \%$ between 1995-2005, whereas it was 31\% between 1965-1985 (2,3,4). Neurosyphilis should be kept in mind in differentional diagnosis of syndromes presenting with various neurologic symptoms. We describe a patient with neurosyphilis, who presented with cranial nerve involvement and atypical clinical features.

\section{Case Report}

A 49-year-old male was admitted with the complaints of double vision for 2 months and left droopy upper eyelid for 1 month. He described that his left upper eyelid improved and then became droopy again during the day. He told that first his right upper eyelid was droopy, then improved and recurred in his left upper eyelid and then he had numbness on the left side of his face. He had hypertension in his medical history. He had been smoking 2 pockets of cigarettes per day for 35 years. He had not consume alcohol or drugs. He was working as a truck driver.

In neurologic examination, direct and indirect pupillary reactions were absent. Movement of the left eye was restricted to all directions while lateral movements of the right eye was restricted. He had semi-ptosis on the left side (Figure 1A). He did not have muscle weakness. Deep tendon reflexes were hyperactive in the lower extremities and he had Babinski sign on the right side. The examination of visual field, visual acuity and intraocular pressure were normal and spectral optic coherence tomography revealed normal findings. The cover-uncover, Hirschberg, color vision, Titmus and Worth 4 dot tests all resulted normal.

The laboratory findings were as follows: White blood cells: 6.27 K/uL (3.5-10.5), hemoglobin: $15.1 \mathrm{~g} / \mathrm{dL}$ (13.5-17.5), thrombocytes: $265 \mathrm{~K} / \mathrm{uL}$ (150-450), B12: $1119 \mathrm{pg} / \mathrm{mL}$ (211-911), folic acid: > 24 $\mathrm{ng} / \mathrm{mL}$ (9-24), glucose: $126 \mathrm{mg} / \mathrm{dL}$ (70-110), urea: $76.6 \mathrm{mg} / \mathrm{dL}$ (18-55), HbA1c: 5.6 (4-6), procalsitonin: $0.12 \mathrm{ng} / \mathrm{mL}$ (0.1-0.5), C-reactive protein: $4.78 \mathrm{mg} / \mathrm{L}(0-5)$, erythrocyte sedimentation rate: $5 \mathrm{~m} / \mathrm{h}(0-20)$, thyroid stimulating hormone: $0.67 \mu \mathrm{IU} / \mathrm{mL}$ (0.56-5.57), free T3 and T4, thyroglobulin, thyroid antibodies, liver function tests, creatinine phophokinase, electrolytes and arterial blood gas test resulted within normal limits. Blood tests for vasculitis and granulamatous diseases resulted negative.

Cranial magnetic resonance imaging (MRI) showed milimetric ischemic lesions in the right cerebellar hemisphere, minimal fluid accumulation around bilateral optic nerves near orbital globes and partial empty sella. There was no contrast enhancement. Cranial MR angiography resulted normal (Figure 2). Cranial MR venography, orbital MRI and temporal bone MRI resulted normal.

A lumbar puncture was performed. Opening pressure of cerebrospinal fluid (CSF) was $160 \mathrm{mmH} 2 \mathrm{O}$. CSF glucose was 65 $\mathrm{mg} / \mathrm{dL}$ and simultaneous blood glucose was $120 \mathrm{mg} / \mathrm{dL}$. CSF protein was $66.9 \mathrm{mg} / \mathrm{dL}$ (15-45). Oligoclonal bands were detected in CSF (pattern 2) and immunoglobulin G index was 0.68 (<0.85). Eighty eight lymphocytes were detected in CSF smear. Microscopy of both stained and non-stained preparations revealed no bacteria and there was no bacterial growth in the culture. Serologic examination for HIV and hepatitis, and molecular analysis of CSF resulted negative. The conduction speed, latency and amplitude of motor and sensorial nerves in electroneurography were normal. Repetitive nerve stimulation resulted normal. Ice test for myasthenia gravis resulted negative. Neostigmine $1 \mathrm{mg}$ intramuscular injection did not lead to any improvement in occular findings. Venereal disease research laboratory (VDRL) test in blood and CSF resulted positive (1/128). Treponema pallidum indirect hemagglutination test (1/10240) and fluorescent treponemal antibody absorption (FTA-Abs) test $(1 / 10)$ resulted positive.

Clinical, radiological and microbiological findings were consulted to the department of infectious diseases and the patient was diagnosed as neurosyphilis. The patient was treated with penicillin 4.000 .000 units 6 times a day. On the $7^{\text {th }}$ day of the treatment, CSF protein was found to be $63.9 \mathrm{mg} / \mathrm{dL}$ (15-45). Sixty six lymphocytes were detected in CSF smear. On the $15^{\text {th }}$ day of the treatment, numbness of the left side of his face improved but there was no significant improvement in ocular findings. $\mathrm{He}$ refused to have another lumbar puncture procedure in the first month of the treatment. Mild improvement was achieved in ocular findings (Figure 1B). Numbness of the face completely resolved and diplopia partially improved.

\section{Discussion}

Neurosyphilis is a spirochete infection which involves central nervous system and caused by Treponema pallidum. It is usually seen in the late stages of the infection but it can also be seen in every stage of the infection. Recently, atypical presentations of the
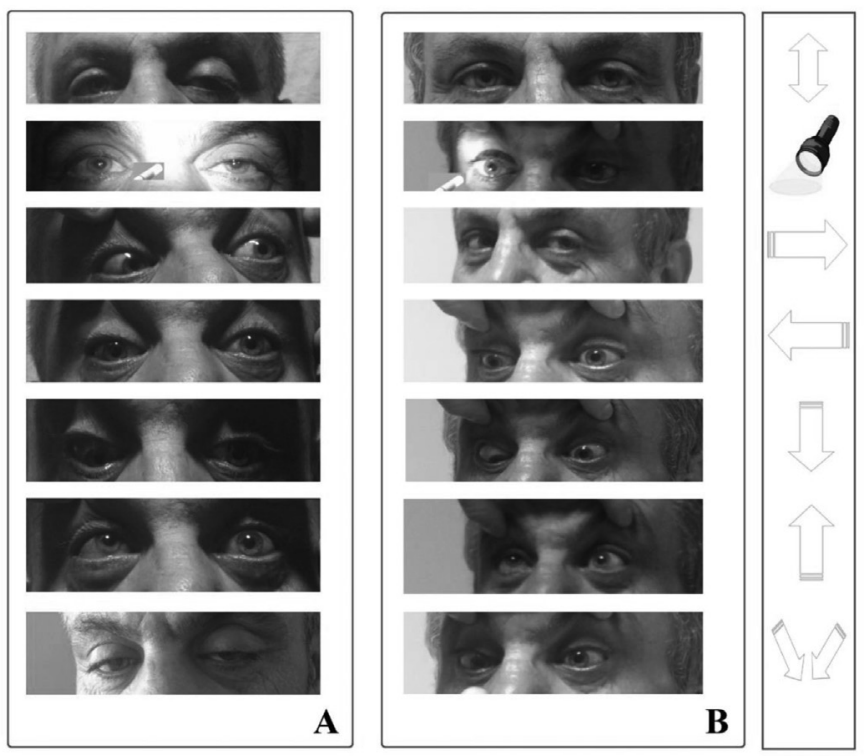

Figure 1. A) At admission: No reaction to light in pupils. Movements of left eye was restricted to all directions while movement of right eye to lateral was restricted. Semi-ptosis was detected on the left side. B) Control after treatment: No reaction to light in pupils. Improvement in the upward, downward and medial movements of the left eye and in semiptosis. 

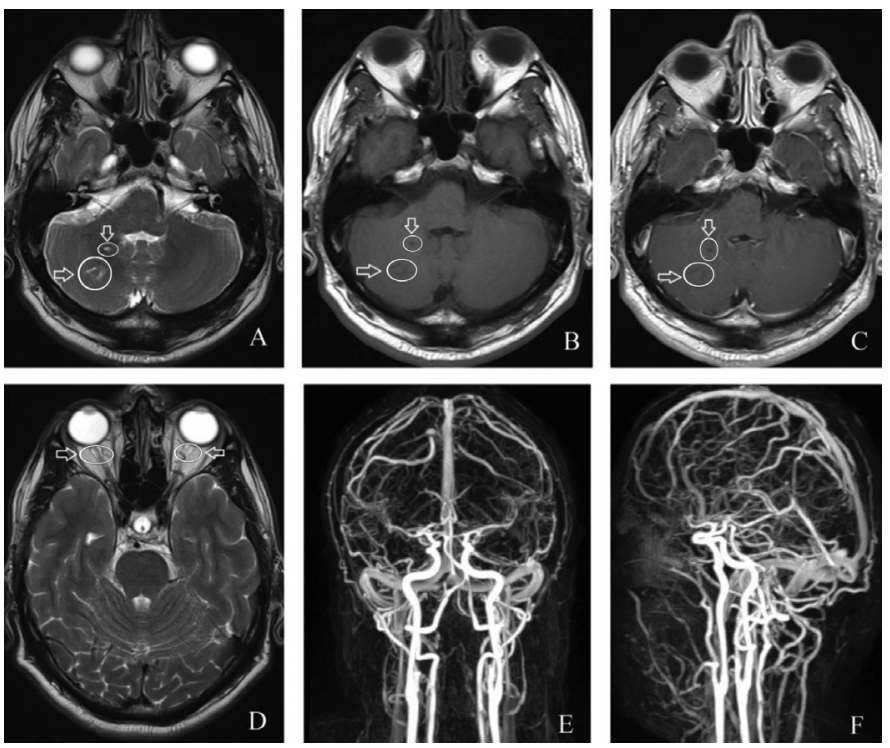

Figure 2. Magnetic resonance imaging A) T2-axial, B) T1 axial, C) T1-axial and contrast, D) T2-axial, E, F) Vascular imaging. Milimetric ischemic lesions in the right cerebellar hemisphere, minimal accumulation of fluid around bilateral optic nerves. There was no contrast enhancement. Vascular structures were normal

disease have increased in frequency which was thought to be due to increased HIV infection frequency and widespread unnecessary antibiotic use in the population (especially, $\beta$-lactamase inhibitors) (4). Atypical presentations cause delays in the diagnosis and treatment and result in bad prognosis.

Neurosyphilis presents with 4 different clinical forms: Asymptomatic (most frequent), meningeal, meningovascular and parenchymal forms (2).

Parenchymal neurosyphilis develops 10-30 years after the initiation of the infection and is caused by lymphoplasmocytic infiltration of small cortical vessels. It presents with neurocognitive impairment such as dementia and behavioral changes. Dementia may have an acute-onset or may be insidious and progressive $(5,6)$. Personality changes, amnesia and inconsistent speech are the most frequent findings. Confusion, hypersomnia, delusions and depresion are rarely seen. Delirium, muscle weakness, aphasia and dysarthria are reported in many studies $(5,7)$. Although cognitive impairment is usually reported, our patient did not have findings or symptoms suggestive of cognitive impairment and his cognitive examination was normal.

Meningovascular syphilis develops 5-10 years after the initiation of the infection and presents with ischemic and rarely with hemorrhagic stroke (8).

Cranial neuropathies are seen especially in syphilitic basilar meningitis. The most commonly involved cranial nerves are $8^{\text {th }}$, $7^{\text {th }}, 2^{\text {nd }}, 3^{\text {rd }}, 4^{\text {th }}$ and $6^{\text {th }}$ nerves respectively according to case reports $(2,3,9,10)$. Syphilis may present with various ocular symptoms. First sign may be pain in the eyes and decrease in visual acuity. Panuveitis, papilledema, retinitis, chorioretinitis, irregular-edged tonic pupil unresponsive to light (Argyll-Robertson pupil) and rarely retinal detachment can be seen (11). Pure ocular impairment leads to a suspicion about cranial involvement of neurosyphilis.
Cranial imaging may not show any relevant abnormalities as in our patient. Neurologic examination and serologic investigation are important beside ophthalmologic examination in the diagnosis of syphilis. Fluctuating ocular symptoms may initially implicate neuromuscular junction disorder, but, as in our patient, if the examination for myasthenia gravis results negative, then neurosyphilis should be kept in mind in differential diagnosis.

Although having low specifity and sensitivity, cranial MRI plays an important role in evaluating the disease and distinguishing it from other diseases. Especially, when small or medium-sized arteries are affected by a vasculitic process, than cranial MRI may show findings reflecting this process. Ischemic lesions in different territories and at different ages can be seen. Lesions which are hypointense in T1- and hyperintense in T2/ FLAIR-weighted images, edema around lesions, mild contrast enhancement and meningeal involvement are frequent findings. Leisons may be isointense in T1- and iso/hypointense in T2weighted images. Non-specific white matter lesions especially involving frontotemporal areas can be seen. Relative dilatation of ventricles due to atrophy can be seen. Normal cranial MRI findings are also commonly seen (12). These findings suggest that cranial MRI has a limited function in the diagnosis of syphilis but it plays an important role in excluding other diseases.

Laboratory-supported diagnosis of neurosyphilis is based on the investigation of CSF sample. Lymphocytic pleocytosis in microscopy is important for the diagnosis. VDRL and FTA-Abs are more specific biomarkers. Reactive VDRL response in CSF confirms the diagnosis but it has a low sensitivity and it can not detect all the patients. FTA-Abs in CSF is more sensitive than VDRL and it is one of the most important diagnostic tools used in detection of patients with asymptomatic syphilis. But it has a high rate of false positivity as a disadvantage (13). Because of this, we performed both tests in our patient. A serologic investigation for HIV should be performed in patients with a suspicion of neurosyphilis, because they have a high rate of coexistence.

High dose intravenous crystalline penicillin should be used in the treatment of neurosyphilis. Response to treatment is followed by repetitive CSF investigations. Decrease in cell count in CSF reflects good response. Patients usually respond well to penicillin treatment in 14 to 21 days but the treatment may need to be repeated (14). Our patient also responded well to high dose penicillin treatment. Numbness of the face completely resolved and ophthalmoparesis partially improved and there was a decrease in the clinical complaints of the patient.

The diagnosis of neurosyphilis is delayed due to its different clinical presentations rather than its rarity. The information that the patient had sexual relationship with different partners led us suspect from neurosyphilis as a diagosis and it was confirmed by the serologic tests in blood and CSF. Neurosyphilis should be kept in mind in differential diagnosis of patients presenting with atypical clinical pictures. Early diagnosis and treatment of rare and treatable infections such as neurosyphilis is crucial.

\section{Ethics}

Informed Consent: The informed consent on sharing patient's details and images with scientific purposes was obtained from patient.

Peer-review: Externally and internally peer-reviewed. 


\section{Authorship Contributions}

Surgical and Medical Practices: F.E., A.H.E., Concept: F.E., R.A., Design: F.E., R.A., Data Collection or Processing: F.E., Ş.Ö., Analysis or Interpretation: F.E., Ş.Ö., Literature Search: F.E., A.H.E., Writing: F.E.

Conflict of Interest: No conflict of interest was declared by the authors.

Financial Disclosure: The authors declared that this study received no financial support.

\section{References}

1. Workowski KA, Bergman S. Sexually transmitted diseases guidelines 2010 . MMWR Recomm Rep 2010;59:1-110.

2. Bhai S, Lyons JL. Neurosyphilis update: atypical is the new typical. Curr Infect Dis Rep 2015;17:20.

3. Mitsonis $\mathrm{CH}$, Kararizou E, Dimopoulos $\mathrm{N}$, et al. Incidence and clinical presentation of neurosyphilis: a retrospective study of 81 cases. Int J Neurosci 2008;118:1251-1257.

4. Barry GH, Miriam B. Evolution of the serine $\beta$-lactamases: past, present and future. Drug Resist Updat 2004;7:111-123.

5. Kinson RM, Chan LG. Psychiatric symptoms as the sole manifestation of neurosyphilis. J Neuropsychiatry Clin Neurosci 2013;25:39-40.
6. Stefani A, Riello M, Rossini F, et al. Neurosyphilis manifesting with rapidly progressive dementia: report of three cases. Neurol Sci 2013;34:20272030.

7. Zhang HL, Lin LR, Liu GL, et al. Clinical spectrum of neurosyphilis among HIV-negative patients in the modern era. Dermatology 2013;226:148156.

8. Liu LL, Zheng WH, Tong ML, et al. Ischemic stroke as a primary symptom of neurosyphilis among HIV negative emergency patients. J Neurol Sci 2012;317:35-39.

9. Hess CW, Rosenfeld SS, Resor SR. Oculomotor nerve palsy as the presenting symptom of gummatous neurosyphilis and human immunodeficiency virus infection clinical response to treatment. JAMA Neurol 2013;70:1582-1583.

10. Alqahtani S. Acute cranial neuropathies heralding neurosyphilis in human immunodeficiency virus-infected patient. Am J Case Rep 2014;15:411415.

11. Marra CM. Update on neurosyphilis. Curr Infect Dis Rep 2009;11:127-134.

12. Peng $\mathrm{F}, \mathrm{Hu} \mathrm{X}$, Zhong $\mathrm{X}$, et al. CT and MR findings in HIV-negative neurosyphilis. Eur J Radiol 2008;66:1-6.

13. Harding AS, Ghanem KG. The performance of cerebrospinal fluid treponemal 386 specific antibody tests in neurosyphilis: a systematic review. Sex Transm Dis 2012;39:291-297.

14. Clement ME, Okeke NL, Hicks CB. Treatment of Syphilis A Systematic Review. JAMA 2014;312:1905-1917. 